\title{
Pemanfaatan Teknologi Dalam Upaya Pemberdayaan Perempuan Melalui Peningkatan Kreativitas Istri Pembudidaya Ikan Patin Di Desa Cindai Alus
}

\author{
Heri Budi Santoso 1), Badruzsaufari 2), Hidayaturrahmah ${ }^{3)}$, Fadlilaturrahmah ${ }^{4 \text { * }}$ \\ Biology Department, Lambung Mangkurat University , Banjarbaru, South Kalimantan, \\ Indonesia \\ 1heribudisantoso@yahoo.com \\ Biology Department, Lambung Mangkurat University , Banjarbaru, South Kalimantan, \\ Indonesia \\ 2badruzsaufari@gmail.com \\ Biology Department, Lambung Mangkurat University , Banjarbaru, South Kalimantan, \\ Indonesia \\ 3rahmahidayahipb09@yahoo.com \\ Food and Pharmacy Analysis Department, Lambung Mangkurat University , Banjarbaru, \\ South Kalimantan, Indonesia \\ 4fadlilaturrahmah@ulm.ac.id
}

Artikel diterima: 04-10-2019, direvisi: 13-11-2019, diterbitkan: 25-12-2019

\begin{abstract}
Abstrak
Pemanfaatan teknologi merupakan salah satu upaya untuk mnghadapi revolusi industri 4.0. Istri-istri pembudidaya ikan patin merupakan kelompok warga yang nonproduktif. Dengan adanya pemanfaatn teknologi dalam upaya pemberdayaan perempuan melalui peningkatan kreativitas istri-istri pembudidaya diharapkan dapat memacu semangat istri-istri pembudidaya patin untuk dapat meningkatkan kreativitas sehingga diharapkan menjadi warga yang produktif. Cindai Alus merupakan daerah penghasil ikan patin terbesar di Kalimantan. Metode yang digunakan adalah survey ke lokasi, sosialisasi program dan pelatihan penggunaan alat-alat.teknologi tepat guna seperti oven untuk pembuatan biskuit skala industry dan mesin pembuat es krim. Berdasarkan hasil survey yang dilakukan tim pengabdian, istri-istri pembudidaya ikan patin di Cindai Alus sudah sering mendapatkan pelatihan pembuatan berbagai macam olahan patin namun belum ada produk yang menarik dan berpotensi dikembangkan bagi warga Cindai Alus dan tidak ada pendampingan setelah dilakukan pelatihan, sehingga warga tidak tertarik untuk menerapkan ilmu yang didapat dari pelatihan. Kreativitas yang diberikan berupa pelatihan cara pembuatan biscuit dan es krim serta penggunaan oven untuk skala industry dan mesin pembuat es krim dari ikan patin. Hasil dari pemanfaatan teknologi ini adalah menambah motivasi dan semanagat untuk dapat meningkatakan kreativitas yang tidak hanya bermanfaat bagi diri sendiri tetapi mampu meningkatkan perekonomian keluarga.
\end{abstract}

Kata Kunci: istri pembudidaya ikan patin, kreativitas, teknologi 


\begin{abstract}
Utilization of technology is one of the efforts to deal with the industrial revolution 4.0. Wives of catfish farmers are non-productive citizens. With the use of technology in efforts to empower women through enhancing the creativity of cultivators 'wives, it is hoped that it can spur the spirit of catfish cultivators' wives to increase creativity so that they are expected to become productive citizens. Cindai Alus is the largest catfish-producing area in Kalimantan. The method used is a site survey, program socialization and training in the use of appropriate technology tools such as industrial scale ovens and ice cream making machines. Based on the results of a survey conducted by the devotion team, the wives of catfish farmers in Cindai Alus have often received training in making various kinds of processed catfish but there are no interesting products and potential to be developed for the citizens of Cindai Alus and there is no assistance after the training, so that residents do not interested in applying the knowledge gained from training. The creativity provided was in the form of training on how to make biscuits and ice cream and the use of ovens for industrial scale and ice cream making machines from catfish. The result of using this technology is to increase motivation and enthusiasm to be able to increase creativity which is not only beneficial for oneself but can improve the family economy.
\end{abstract}

Keywords: wives of catfish farmers, creativity, technology

\section{Pendahuluan}

Cindai Alus adalah salah satu kelurahan di kabupaten Banjar yang dicanangkan sebagai kota minapolitan penghasil ikan patin. Data sementara produksi Patin di Propinsi Kalimantan Selatan pada 2014 adalah 25,5 ribu ton. Volume ini setara dengan 6,3\% produksi patin nasional yang mencapai 403 ribu ton. Target produksi patin nasional pada 2015 adalah 604,7 ribu ton dengan target kontribusi produksi dari Kalimantan Selatan sebesar 48,6 ribu ton. Dalam satu hari, kawasan minapolitan Cindai Alus mampu menghasilkan 35 - 40 ton patin. Istriistri para pembudidaya ikan di Cindai Alus yang tidak memiliki pekerjaan dan masih berada diusia produktif berpotensi untuk diberikan wawasan dalam pengembangan produk olahan ikan patin yaitu biskuit dan es krim.
Biskuit adalah produk yang diperoleh dengan memanggang adonan dari tepung terigu dengan penambahan bahan makanan lain dan dengan atau tanpa penambahan bahan tambahan pangan yang diizinkan (Wijaya (2010). Syarat mutu biskuit adalah air maksimum 5\%; protein minimum 9\%; lemak minimum 9,5\%; karbohidrat minimum 70\%; abu maksimum 1,5\%; logam berbahaya negatif; serat kasar maksimum 0,5\%; kalori minimum 400 kal/ 100 gram; jenis tepung adalah terigu; bau dan rasa normal, tidak tengik; dan warnanya normal (SNI 012973-1992). Kandungan glukosa biskuit diet diabetes maksimal $1 \%$ dan protein minimal 4\% (SNI, 1995).

Pada masa kini produk biskuit yang beredar dipasaran pada umumnya mengandung minyak nabati, lemak susu dan minyak dari ikan air laut. Padahal ekstrak minyak dari ikan air tawar 
sebagai pangan fungsional mampu mempengaruhi kesehatan. Sehingga potensi ekstrak minyak ikan dari air tawar tidak kalah bagusnya sebagai bahan alami dalam pembuatan biskuit karena mengandung omega 3 dan omega 6 untuk menormalkan kadar glukosa darah. Salah satu produk pangan fungsional yang berasal dari hasil perikanan disekitar kita adalah ikan air tawar yang dikenal sebagai sumber protein bermutu tinggi, seperti ikan patin. Ikan patin merupakan ikan yang memiliki karakteristik berbeda dibandingkan dengan jenis ikan air tawar lainnya yaitu memiliki daging yang berukuran besar dan berwarna putih. Ikan patin mempunyai kandungan lemak yang cukup banyak dibandingkan dengan jenis ikan air tawar lainnya yaitu sekitar $40 \%$.

Strategi yang dapat dilakukan untuk memperlambat DM adalah dengan mengatur pola makan atau diet yang dapat dilakukan melalui pengendalian kadar glukosa darah. Pemilihan jumlah dan jenis karbohidrat yang tepat dengan konsumsi makanan bernilai Indeks Glikemik (IG) rendah (Serena, 2004), dimana konsep IG menekankan pada pentingnya mengenal karbohidrat berdasarkan kecepatannya menaikkan kadar glukosa darah setelah pangan tersebut dikonsumsi. Konsep IG berguna untuk semua orang, antara lain orang yang mengalami obesitas, diabetes, atlet, bahkan orang sehat sekalipun (Rimbawan dan Siagian, 2004).

Oleh karena itu, diperlukan suatu produk olahan pangan yang siap sedia dikonsumsi, dapat dijadikan produk antara bagi sediaan untuk obat anti diabetes dan berpotensi besar memiliki IG rendah. Untuk dapat membuat produk olahan tersebut dan untuk memberikan motivasi pada istri-istri pembudidaya ikan patin di Cindai Alus, maka diberikan teknologi berupa oven untuk membuat biskuit dan mesin pembuat es krim sehingga istr-istri pembudidaya ikan dapat bersemangat untuk meningkatkan kreativitas.

\section{Metode}

Metode yang digunakan adalah survey ke lokasi dan berkoordinasi dengan para istri-istri pembudidaya ikan patin, sosialisasi program dan pelatihan penggunaan alat-alat teknologi tepat guna seperti oven untuk pembuatan biskuit skala industry dan mesin pembuat es krim.

\section{Hasil dan Pembahasan}

Pengabdian kemitraan masyarakat ini bekerja sama dengan "UPR (Unit Pembenihan dan Peremajaan) Ikan Berkah" yang terletak di Cindai Alus Kabupaten Banjar. Pengabdian ini diawali dengan survey kelokasi dan berkoordinasi dengan para istri-istri pembudidaya ikan patin mengenai program pengabdian masyarakat ini. 
Setelah dilakukan survey dilanjutkan dengan berkoordinasi mengenai jadwal pelatihan agar dapat dikumpulkan istriistri pembudidaya ikan patin yang berada disekitar UPR Berkah.

Istri-istri para pembudidaya ikan di Cindai Alus sebagain besar tidak memiliki pekerjaan dan masih berada diusia produktif berpotensi untuk diberikan wawasan dalam pengembangan produk olahan ikan patin yaitu biskuit dan es krim. Berdasakan hasil survey dan koordinasi dengan para istri-istri pembudidaya ikan patin, bahwa mereka sudah banyak mendapatkan pelatihan mengenai cara pembuatan produk olahan patin tetapi mereka belum tertarik untuk mengembangkan produk tersebut. Dengan pemberian pelatihan disertai dengan pemberian teknologi diharapkan para istriistri pembudidaya ikan bersemangat untuk membuat produk olahan ikan patin berupa biscuit dan es krim. Kegiatan diawali dengan pemberian materi mengenai manfaat ikan patin dan cara pembuatan biscuit dan es krim. Selanjutnya dilakukan praktek pembuatan biscuit dan es krim menggunakan pemanfaatan tenologi yang diberikan berupa oven pembuat biscuit dan mesin es krim.

Bahan-bahan pembuatan biskuit terdiri dari tepung terigu, filtrat ikan patin, mentega, butter, kuning telur, gula, vanili, perasa makanan, dan meses seres. Setelah semua adonan dicampur dibentuk menjadi biskuit sesuai dengan selera agar terlihat menarik. Bahan-bahan pembuatan es krim terdiri dari filtrate ikan patin, susu bubuk, susu kental manis putih, tepung meizena, air, gula pasir, bahan perasa, garam dan vanili. Setelah semua bahan dicampur, agar mendapatkan hasil es krim yang lembut maka dimixer kemudian dimasukkan kedalam mesin pembuat es krim. Mesin pembuat es krim dijalankan selama 1 jam sehingga mendapatkan hasil es krim yang lembut.

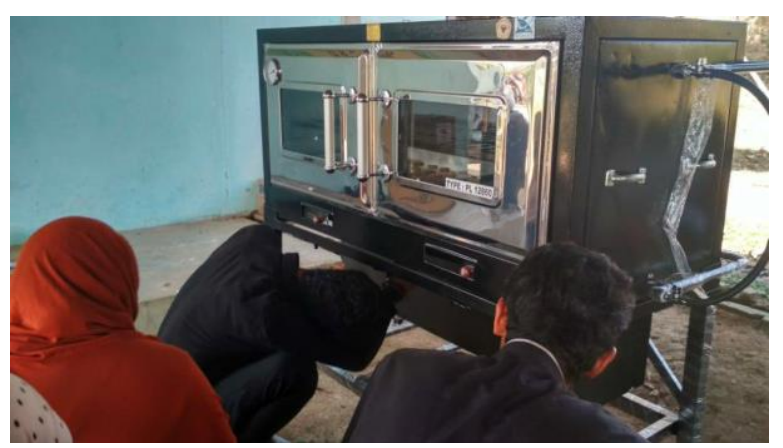

Gambar 1. Oven biscuit

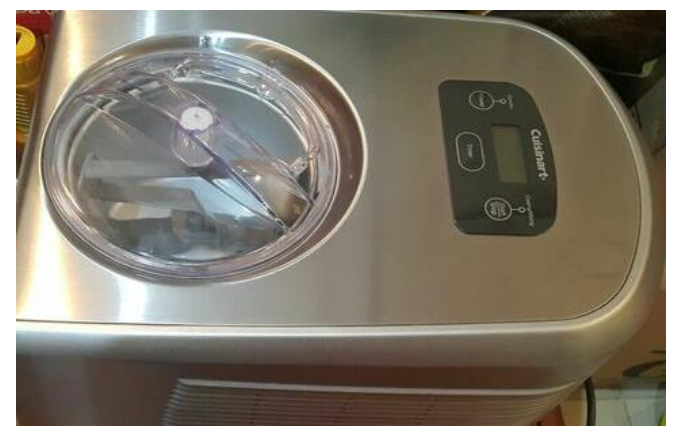

Gambar 2. Mesin Pembuat es krim 


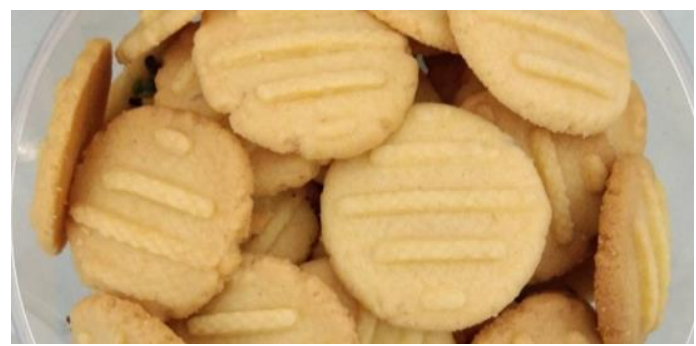

Gambar 3. Biskuit hasil pelatihan

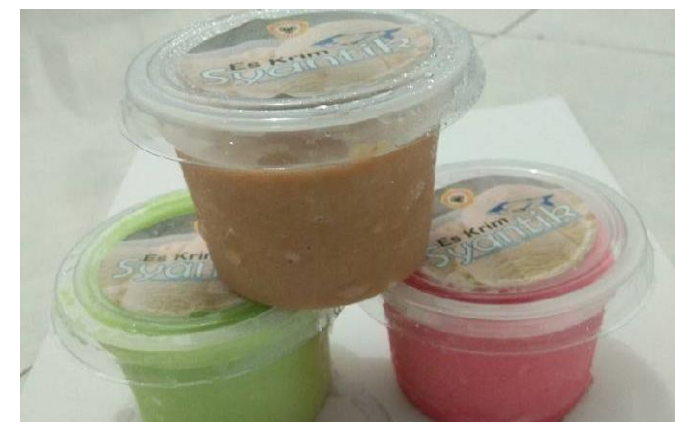

Gambar 4. Es krim hasil pelatihan

Praktek pembuatan biscuit dan es krim disertai dengan penjelasan cara penggunaan oven dan mesin pembuat es krim. Hasil dari kegiatan ini istri-istri pembudidaya ikan patin sangat tertarik untuk mengembangkan produk olahan patin berupa biscuit dan es krim karena proses pembuatannya dipermudah dengan adanya penerapan teknologi yang diberikan yaitu oven dan mesin pembuat es krim.

\section{Penutup}

Pemanfaatan teknologi dalam upaya pemberdayaan perempuan diharapkan dapat meningkatkan kreativitas istri-istri pembudidaya ikan patin didesa Cindai Alus.

Saran yang diberikan untuk pengabdian kali ini adalah perlunya pendampingan bagi istri-istri pembudidaya ikan patin sehingga dapat meningkatkan penghasilan keluarga.

\section{UCAPAN TERIMA KASIH}

Tim pengabdian masyarakat mengucapkan banyak terima kasih kepada Kemenristekdikti dan LPPM ULM atas dukungan material sehingga program pengabdian masyarakat ini dapat terlaksana.

\section{Daftar Pustaka}

Afriansyah, E.A. $\left(2012^{\mathrm{a}}\right)$. Design Research: Konsep Nilai Tempat dalam Operasi Penjumlahan Bilangan Desimal di Kelas V Dekolah Dasar. Tesis Magister pada SPS UNSRI-UTRECHT: Tidak diterbitkan.

Badan Standarisasi Nasional. (1992). SNI 01-2973-1992. Syarat Mutu dan Cara Uji Biskuit. Jakarta. Badan Standarisasi Nasional.

Dep. Perindustirian. (2003). Biskuit. Penanganan Gizi Buruk. Jakarta.

Hidayaturrahmah, Santoso H.B., Nurlely. (2016). Profil Glukosa darah tikus setelah pemberian ekstrak minyak ikan patin sebagai alternative antidiabetes. Laporan penelitan. Banjarbaru. DIPA FMIPA ULM.

Rimbawan, dan Siagian A. (2004). Indeks Glikemia Pangan. Penerbit Swadaya

Winarno, FG. (2002). Kimia Pangan dan Gizi. Jakarta. Gramedia.

\section{Riwayat Hidup Penulis}

Drs.Heri Budi Santoso, M.Si. Lahir di Pati, 11 September 1969. Penulis mengambil program studi strata 1 pada tahun 1987 ,

Jian Kepada Masyarakat MEDITEG Volume 4, Nomor 2, Desember 2019 dian Kepada Masyarakat MEDITEG 
di FMIPA Universitas Jenderal Soedirman pada bidang ilmu Zoologi. Kemudian melanjutkan program studi magister di FMIPA Universitas Gadjah Mada pada bidang ilmu embriologi hewan (teratologi) pada tahun 1996. Penulis sekarang aktif sebagai dosen pengajar di program studi Biologi FMIPA Universitas Lambung Mangkurat.

Dr.Ir.Badruzsaufari,M.Sc.

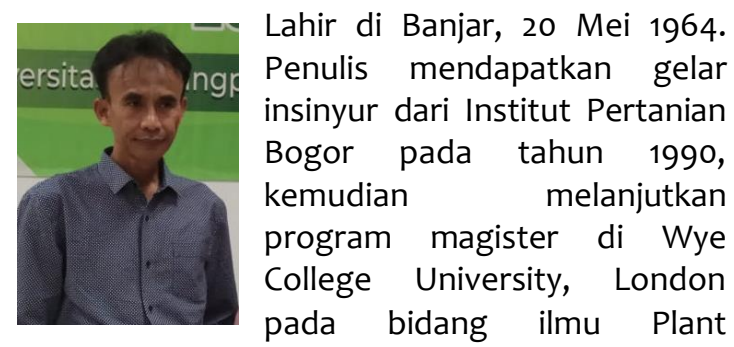
Biotechnology dan lulus pada tahun 1995. Pada tahun 2005, penulis melanjutkan program doctoral di University of Queensland Australia. Penulis sekarang aktif sebagai dosen pengajar di program studi Biologi FMIPA Universitas Lambung Mangkurat.

\section{Hidayaturrahmah,M.Si.}

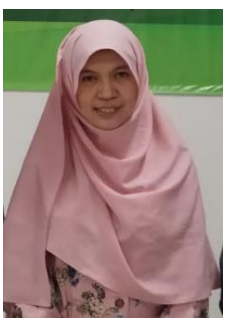

Lahir di Karang Intan, 14 Desember 1981. Penulis menyelesaikan program strata 1 pada program studi biologi FMIPA Universitas Lambung Mangkurat, Banjarbaru pada tahun 2004. Pada tahun yang sama penulis diterima sebagai dosen honorer ditempat penulis berkuliah. Kemudian penulis melanjutkan program magister di fakultas kedokteran hewan Institut Pertanian Bogor pada tahun 2009 dan mendapatkan gelar M.Si pada tahun 2011. Sekarang penulis aktif sebagai dosen di program studi Biologi, FMIPA, Universitas Lambung Mangkurat.

\section{Fadlilaturrahmah,M.Sc.Apt.}

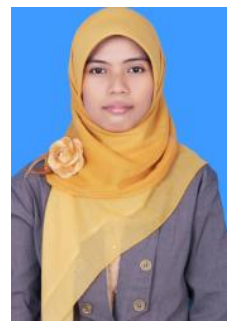

Lahir di Karang Intan, 8 Juni 1986. Penulis menyelesaikan program strata 1 dibidang farmasi pada program studi farmasi FMIPA Universitas Lambung Mangkurat, Banjarbaru pada tahun 2009 dan melanjutkan program profesi apoteker di Universitas Airlangga, Surabaya dan lulus pada tahun 2011. Pada tahun yang sama penulis melanjutkan program magister ilmu farmasi dengan konsentrasi Pengendalian Kualitas Obat dan Makanan pada Fakultas Farmasi Universitas Gadjah Mada, Yogyakarta serta lulus tahun 2013. Sejak lulus tahun 2013, penulis mengabdi kealmamater sebagai dosen di Universitas Lambung Mangkurat sampai sekarang. 